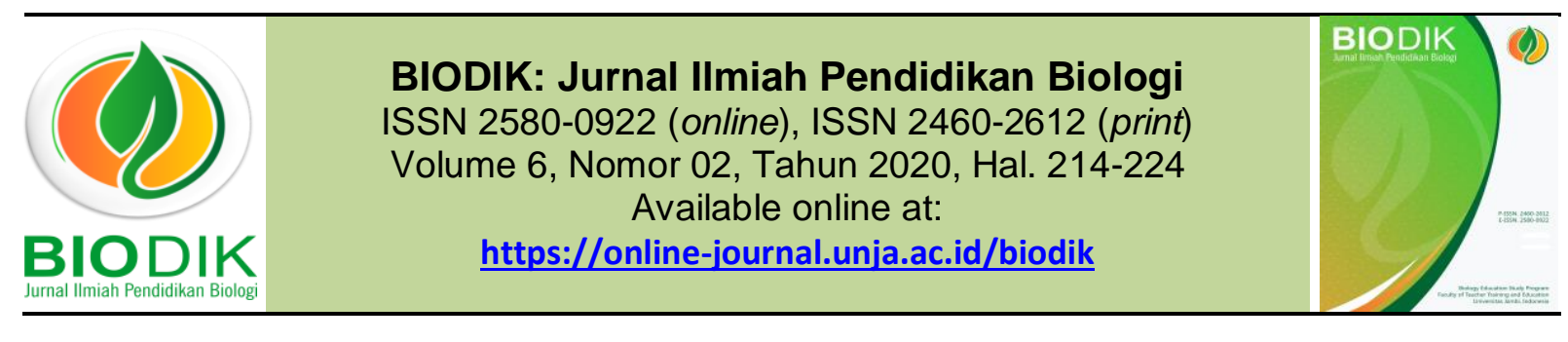

Research Article

\title{
Pembelajaran Daring di Tengah Wabah Covid-19
}

\section{(Online Learning in the Middle of the Covid-19 Pandemic)}

\begin{tabular}{|c|c|}
\hline \multicolumn{2}{|c|}{$\begin{array}{l}\text { Program Studi Pendidikan Biologi FKIP Universitas Jambi } \\
\text { Kampus Pinang Masak Jl. Jambi Ma. Bulian KM.15 Mendalo Indah, } \\
\text { Kec. Jaluko Kab. Muarojambi-Jambi Kode Pos 36361- Indonesia } \\
{ }^{*} \text { Corresponding Author: alisadikin@unja.ac.id }\end{array}$} \\
\hline Informasi Artikel & $\overline{\text { ABSTRACT }}$ \\
\hline $\begin{array}{l}\text { Submit: } 21-05-2020 \\
\text { Diterima: } 27-06-2020 \\
\text { Dipublikasikan:30 - } 06-2020\end{array}$ & $\begin{array}{l}\text { Corona Virus Disease } 2019 \text { (Covid-19) has disrupted conventional } \\
\text { learning process. The refore we need a solution to The challage. } \\
\text { Online learning is one alternative that can overcome the } \\
\text { challenge.This aimed at obtaining an overview of the implementation } \\
\text { of online learning in Biology Education Study Program, Faculty of } \\
\text { Education, Jambi University as an effort to suppress the spread of co- } \\
19 \text { in Higher Education. Research samples were students of Biology } \\
\text { Education Study Program. Data were collected by interview through a } \\
\text { zoom cloud meeting. Data analysis was performed using the } \\
\text { interactive analysis technique of Miles \& Huberman. The results } \\
\text { showed that: (1) students already have the basic facilities needed to } \\
\text { take part in online learning; (2) online learning has flexibility in its } \\
\text { implementation and is able to encourage the emergence of } \\
\text { independent learning and motivate students to be more active in } \\
\text { learning; and (3) distance learning encourages the emergence of } \\
\text { social distancing behavior and minimizes the emergence of student } \\
\text { crowds so that it might be able to reduce the potential for the spread } \\
\text { of Covid-19 in the college environment. Weak supervision of students, } \\
\text { lack of signal strength in remote areas, and the high cost of internet } \\
\text { credits challenge in on line learning. Increasing learning } \\
\text { independence, interest and motivation, the courage to express ideas } \\
\text { and questions other benefits of online learning. } \\
\text { Keywords: Online learning, Covid-19, social distancing }\end{array}$ \\
\hline & ABSTRAK \\
\hline $\begin{array}{l}\text { Program Studi Pendidikan } \\
\text { Biologi, Fakultas Keguruan dan } \\
\text { IImu Pendidikan, Universitas } \\
\text { Jambi }\end{array}$ & $\begin{array}{l}\text { Pademi covid-19 telah mengganggu proses pembelajaran secara } \\
\text { konvensional. Maka diperlukan solusi untuk menjawab permasalahan } \\
\text { tersebut. Pembelajaran secara daring adalah salah satu alternatif } \\
\text { yang dapat mengatasi masalah tersebut. Tujuan penelitian adalah } \\
\text { untuk memperoleh gambaran pelaksanaan pembelajaran daring di } \\
\text { Prodi Pendidikan Biologi FKIP Universitas Jambi sebagai upaya } \\
\text { menekan penyebaran covid-19 di Perguruan Tinggi. Subjek penelitian } \\
\text { adalah mahasiswa Prodi Pendidikan Biologi. Data dikumpulkan } \\
\text { dengan wawancara melalui zoom cloud meeting. Analisis data } \\
\text { dilakukan menggunakan teknik analisis interaktif Miles \& Huberman. } \\
\text { Hasil penelitian menunjukkan bahwa: (1) mahasiswa telah memiliki } \\
\text { fasilitas-fasilitas dasar yang dibutuhkan untuk mengikuti pembelajaran } \\
\text { daring; (2) pembelajaran daring memiliki fleksibilitas dalam } \\
\text { pelaksanaannya dan mampu mendorong munculnya kemandirian } \\
\text { belajar dan motivasi untuk lebih aktif dalam belajar; dan (3) }\end{array}$ \\
\hline
\end{tabular}



distancing dan meminimalisir munculnya keramaian mahasiswa sehingga dianggap dapat mengurangi potensi penyebaran Covid-19 di lingkungan perguruan tinggi. Lemahnya pengawasan terhadap mahasiswa, kurang kuatnya sinyal di daerah pelosok, dan mahalnya biaya kuota adalah tantangan tersendiri dalam pembelajaran daring. Meningkatkan kemandirian belajar, minat dan motivasi, keberanian mengemukakan gagasan dan pertanyaan adalah keutungan lain dari pembelajaran daring.

Katakunci: Pembelajaran daring, Covid-19, social distancing

\section{PENDAHULUAN}

Wabah corona virus disease 2019 (Covid-19) yang telah melanda 215 negara di dunia, memberikan tantangan tersendiri bagi lembaga pendidikan, khususnya Perguruan Tinggi. Untuk melawan Covid-19 Pemerintah telah melarang untuk berkerumun, pembatasan sosial (social distancing) dan menjaga jarak fisik (physical distancing), memakai masker dan selalu cuci tangan. Melalui Kementerian Pendidikan dan Kebudayaan Pemerintah telah melarang perguruan tinggi untuk melaksanakan perkuliahan tatap muka (konvensional) dan memerintahkan untuk menyelenggarakan perkuliahan atau pembelajaran secara daring (Surat Edaran Kemendikbud Dikti No. 1 tahun 2020). Perguruan tinggi dituntun untuk dapat menyelenggarakan pembelajaran secara daring atau on line (Firman, F., \& Rahayu, S., 2020).

Tidak sedikit universitas dengan cepat merespon intruksi pemerintah, tidak terkecuali Universitas Indonesia (UI) dengan mengeluarkan surat instruksi tentang pencegahan penyebaran corona virus diesease (Covid-19) di lingkungan Universitas Indonesia. Di surat edaran itu ada 10 poin dan salah satunya adalah anjuran untuk menerapkan pembelajaran daring (Yandwiputra, 2020). Ada sekitar 65 perguruan tinggi di Indonesia yang telah melaksanakan pembelajaran daring dalam mengantisipasi penyebaran Covid-19 (CNNIndonesia, 2020). Jamaluddin, D., Ratnasih, T., Gunawan, H., \& Paujiah, E. (2020) menyatakan bahwa pembelajaran daring memiliki kekuatan, tantangan dan hambatan tersendiri.

Untuk mencegah penyebaran Covid-19, WHO memberikan himbauan untuk menghentikan acara-acara yang dapat menyebabkan massa berkerumun. Maka dari itu, pembelajaran tatap muka yang mengumpulkan banyak mahasiswa di dalam kelas ditinjau ulang pelaksanaanya. Perkuliahan harus diselenggarakan dengan skenario yang mampu mencegah berhubungan secara fisik antara mahasiswa dengan dosen maupun mahassiswa dengan mahasiswa (Firman, F., \& Rahayu, S., 2020). Menurut Milman (2015) penggunaan teknologi digital dapat memungkinkan mahasiswa dan dosen melaksanakan proses pembelajaran walaupun mereka ditempat yang berbeda.

Bentuk perkuliahan yang dapat dijadikan solusi dalam masa pandemi covid-19 adalah pembelajaran daring. Menurut Moore, Dickson-Deane, \& Galyen (2011) 
Pembelajaran daring merupakan pembelajaran yang menggunakan jaringan internet dengan aksesibilitas, konektivitas, fleksibilitas, dan kemampuan untuk memunculkan berbagai jenis interaksi pembelajaran. Penelitian yang dikakukan oleh Zhang et al., (2004) menunjukkan bahwa penggunaan internet dan teknologi multimedia mampu merombak cara penyampaian pengetahuan dan dapat menjadi alternatif pembelajaran yang dilaksanakan dalam kelas tradisional. Pembelajaran daring adalah pembelajaran yang mampu mempertemukan mahasiswa dan dosen untuk melaksanakan interaksi pembelajaran dengan bantuan internet (Kuntarto, E. (2017).

Pada tataran pelaksanaanya pembelajaran daring memerlukan dukungan perangkatperangkat mobile seperti smarphone atau telepon adroid, laptop, komputer, tablet, dan iphone yang dapat dipergunakan untuk mengakses informasi kapan saja dan dimana saja (Gikas \& Grant, 2013). Perguruan tinggi pada masa WFH perlu melaksanakan penguatan pembelajaran secara daring (Darmalaksana, 2020). Pembelajaran secara daring telah menjadi tuntutan dunia pendidikan sejak beberapa tahun terakhir (He, Xu, \& Kruck, 2014). Pembelajaran daring dibutuhkan dalam pembelajaran di era revolusi industri 4.0 (Pangondian, R. A., Santosa, P. I., \& Nugroho, E., 2019).

Penggunaan teknologi mobile mempunyai sumbangan besar dalam lembaga pendidikan, termasuk di dalamnya adalah pencapaian tujuan pembelajaran jarak jauh (Korucu \& Alkan, 2011). Berbagai media juga dapat digunakan untuk mendukung pelaksanaan pembelajaran secara daring. Misalnya kelas-kelas virtual menggunakan layanan Google Classroom, Edmodo, dan Schoology (Enriquez, 2014; Sicat, 2015; Iftakhar, 2016), dan applikasi pesan instan seperti WhatsApp (So, 2016). Pembelajaran secara daring bahkan dapat dilakukan melalui media social seperti Facebook dan Instagram (Kumar \& Nanda, 2018). Pembelajaran daring menghubungkan peserta didik dengan sumber belajarnya (database, pakar/instruktur, perpustakaan) yang secara fisik terpisah atau bahkan berjauhan namun dapat saling berkomunikasi, berinteraksi atau berkolaborasi (secara langsung/synchronous dan secara tidak langsung/asynchronous). Pembelajaran daring adalah bentuk pembelajaran jarak jauh yang memanfaatkan teknologi telekomunikasi dan informasi, misalnya internet, CD-ROOM (Molinda, 2005). Tujuan dari penelitian ini adalah untuk memperoleh gambaran pembelajaran daring di Program studi pendidikan biologi FKIP Universitas Jambi semasa pandemi covid-19.

\section{METODE PENELITIAN}

Jenis penelitian yang digunakan adalah penelitian kualitatif. Tujuan penelitian ini adalah menggambarkan pembelajaran daring yang diselenggarakan di Prodi Pendidikan Biologi FKIP Universitas Jambi sebagai upaya dalam menekan mata rantai penyebaran Covid-19 di lingkungan perguruan tinggi. Pembelajaran daring yang dimaksud dalam penelitian ini adalah pembelajaran yang menggunakan mediamedia pembelajaran yang dapat diakeses menggunakan layanan internet. Penelitian dilakukan dengan terlebih dahulu mengadakan survey kepada mahasiswa mengenai penerapan pembelajaran daring. Survey disebarkan menggunakan google form yang diberikan kepada mahasiswa melalui pesan WhatsApp. Ada 96 orang subyek yang telah memberikan respon terhadap survei yang disebarkan. Hasil survey kemudian dikelompokkan kedalam tiga kategori respon mahasiswa: (1) Setuju dengan penerapan pembelajaran daring; (2) Tidak setuju dengan penerapan pembelajaran daring; (3) Ragu dengan pelaksanaan pembelajaran daring.

\section{$216 \quad$ Ali Sadikin. dkk}


Subjek penelitian adalah mahasiswa Program studi Pendidikan Biologi FKIP Universitas Jambi telah melaksanakan pembelajaran daring, dan dikelompokkan berdasarkan respon subjek penelitian. Di dapatkan 12 orang subjek penelitian, 4 orang mahasiswa angkatan 2017, 4 orang mahasiswa angkatan 2018, dan 4 orang mahasiswa angkatan 2019, 8 orang mahasiswa berjenis kelamin laki-laki dan 4 orang mahasiswa berjenis kelamin perempuan. Pengumpulan data dilakukan melalui wawancara via telpon dan atau zoom cloud meeting. Aspek-aspek yang ditanyakan dalam wawancara adalah: (1) sarana dan prasarana yang dimiliki mahasiswa untuk melaksanakan pembelajaran daring; (2) Respon mahasiswa mengenai efektivitas pembelajaran daring; (3) Pelaksanaan pembelajaran daring dalam memutus mata rantai penyebaran Covid-19 di lingkungan perguruan tinggi. Analisis data penelitian dilakukan menggunakan model analisis Miles \& Huberman (1994) yang terdiri dari tiga tahapan, yaitu reduksi data, display data, serta penarikan dan verifikasi kesimpulan.

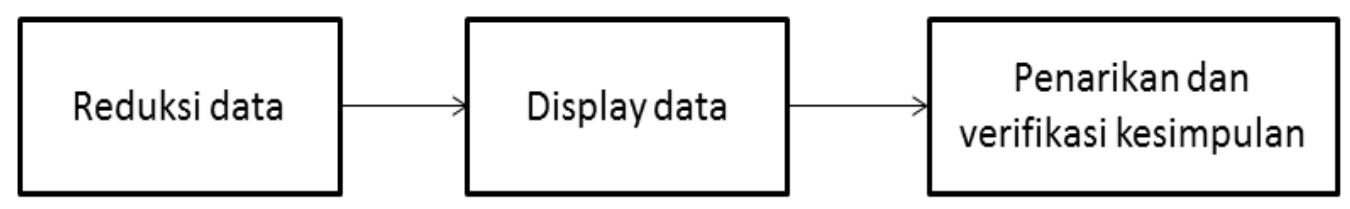

Gambar 1: Tahapan Analisis data penelitian

Analisis data penelitian tahap reduksi data merupakan tahap mengumpulkan seluruh informasi yang dibutuhkan dari hasil wawancara lalu di kelompokkan datanya. Tahap display data merupakan pemaparan data yang diperlukan dalam penelitian dan yang tidak perlu dibuang. Tahap penarikan dan verifikasi kesimpulan adalah tahap interpretasi data penelitian untuk ditarik kesimpulan berdasarkan fenomena yang didapatkan (Miles, M. B., \& Huberman, M.,1994).

\section{HASIL DAN PEMBAHASAN}

1. Mahasiswa memiliki fasilitas yang memadai untuk melaksanakan pembelajaran daring

Peningkatan dalam penggunaan internet di Indoensia dipengaruhi oleh perkembangan teknologi informasi dan komunikasi (Rahadian, D.,2017). Pada tahun 2018 ada $62,41 \%$ orang penduduk Indonesia telah memiliki telepon seluler dan $20,05 \%$ rumah tangga telah memiliki komputer dirumahnya (BPS, 2019). Data ini relevan dengan hasil riset yang memaparkan bahwa walaupun ada mahasiswa yang belum memiliki laptop, akan tetapi hampir seluruh mahasiswa telah mempunyai smartphone. Survey yang telah dilakukan melaporkan bahwa 54 orang mempunyai smartphone dan laptop dan 42 orang mempunyai smartphone saja.

Penggunaan smartphone dan laptop dalam pembelajaran daring dapat meningkatkan hasil belajar peserta didik (Anggrawan, A., 2019). Pangondian, R. A., Santosa, P. I., \& Nugroho, E. (2019) menyatakan banyak kelebihan penggunaan teknologi informasi dan komunikasi dalam pelaksanaan pembelajaran daring 
diantaranya adalah tidak terikat ruang dan waktu. Penelitian telah banyak dilakukan yang meneliti tentang penggunaan gawai serpti smartphone dan laptop dalam pembelajaran. Kemampuan smartphone dan laptop dalam mengakses internet membantu mahasiswa untuk mengikuti pembelajaran daring (Kay \& Lauricella, 2011; Gikas \& Grant, 2013; Chan, Walker, \& Gleaves, 2015; Gokfearslan, Mumcu, Haßlaman, \& £evik, 2016). Penggunaan pembelajaran daring menggunakan zoom cloud meeting memiliki kelebihan dapat berinteraksi langsung antara mahasiswa dan dosen serta bahan ajar tetapi memiliki kelemahan boros kuata dan kurang efektif apabila lebih dari 20 peserta didik (Naserly, M. K.,2020).

Lebih lanjut, tantangan pembelajaran daring adalah ketersediaan layanan internet. Sebagian mahasiswa mengakses internet menggunakan layanan selular, dan sebagian kecil menggunakan layanan WiFi. Ketika kebijakan pembelajaran daring diterapkan di Universitas Jambi, mahasiswa pulang kampung. Mereka mengalami kesulitan sinyal selular ketika di daerah masing-masing, jikapun ada sinyal yang didapatkan sangat lemah. Hal ini menjadi tantangan tersendiri dalam penerapan pembelajaran daring di Universitas Jambi. Pembelajaran daring memiliki kelemahan ketika layanan internet lemah, dan intruksi dosen yang kurang dipahami oleh mahasiswa (Astuti, P., \& Febrian, F.,2019).

Tantang lain yang dihadapi adalah kendala dalam pembiayaan pembelajaran daring. Mahasiswa mengungkapkan bahwa untuk mengikuti pembelajaran daring, mereka harus mengeluarkan biaya cukup mahal untuk membeli kuota data internet. Menurut mereka, pembelajaran dalam bentuk konferensi video telah menghabiskan banyak kuota data, sementara diskusi online melalui applikasi pesan instan tidak membutuhkan banyak kuota. Rata-rata mahasiswa menghabiskan dana Rp. 100.000 sampai Rp. 200.000 per minggu, tergantung provider seluler yang digunakan. Penggunaan pembelajaran daring menggunakan konferensi video membutuhkan biaya yang cukup mahal (Naserly, M. K., 2020).

Walaupun penggunaan gawai dapat mendukung pembelajaran daring, tetapi ada dampak negatif yang perlu mendapat perhatian dan diantisipasi yaitu penggunaan gawai yang berlebihan. Mereka mengakui bahwa selain untuk pembelajaran, mahasiswa juga menggunakan gawai untuk media sosial dan menonton youtube. Media sosial telah memasuki ranah kehidupan golongnan dewasa awal (Lau, 2017). Mahasiswa mengakses media sosial dalam rangka ekspresi diri, membangun jejaring pertemanan dan opini (Kim, Wang, \& Oh, 2016). Sangat disayangkan, banyak orang kecanduang gawai akibat menggunakannya secara berlebihan (Waslh, White \& Young, 2007). Perlu dikhawatirkan masuknya informasi yang menyesatkan dan tidak perhatian selama belajar akibat bermain media sosial (Siddiqui \& Singh, 2016). Selain itu, peserta didik yang kecanduan gawai memiliki masalah akademik dan sosial (Kwon et al., 2013). Peserta didik yang memiliki kecanduan gadget memiliki masalah emosional dan perilaku (Asif, A. R., \& Rahmadi, F. A., 2017).

\section{Efektivitas Pembelajaran daring}

Pembelajaran daring yang dilaksanakan di Program Studi Pendidikan Biologi FKIP Universitas Jambi dalam upaya memutus mata rantai penyebaran Covid-19 menggunakan aplikasi-aplikasi pembelajaran yang dapat diakses dengan jaringan

\section{Ali Sadikin. $\boldsymbol{d k k}$}


internet. Secara keseluruhan, mahasiswa puas dengan pembelajaran yang fleksibel. Dengan pembelajaran daring, mahasiswa tidak terkendala waktu dan tempat dimana mereka dapat mengikuti perkuliahan dari rumah masing-masing maupun dari tempat dimana saja. Dengan pembelajaran daring, dosen memberikan perkuliahan melalui kelas-kelas virtual yang dapat diakses dimana pun dan kapan pun tidak terikat ruang dan waktu. Kondisi ini membuat mahasiswa dapat secara bebas memilih mata kuliah yang dikuti dan tugas mana yang harus dikerjakan lebih dahulu. Penelitian Sun et al., (2008) menginformasikan bahwa fleksibilitas waktu, metode pembelajaran, dan tempat dalam pembelajaran daring berpengaruh terhadap kepuasan mahasiswa terhadap pembelajaran.

Ditemukan hasil penelitian yang unik dari penelitian ini yaitu mahasiswa merasa lebih nyaman dalam mengemukakan gagasan dan pertanyaan dalam pembelajaran daring. Mengikuti pembelajaran dari rumah membuat mereka tidak merasakan tekanan psikologis dari teman sebaya yang biasa mereka alami ketika mengikuti pembelajaran tatap muka. Ketidakhadiran dosen secara langsung atau fisik juga menyebabkan mahasiswa merasa tidak canggung dalam mengutarakan gagasan. Ketiadaaan penghambat fisik serta batasan ruang dan waktu menyebabkan peserta didik lebih nyaman dalam berkomunikasi (Sun et al., 2008). Lebih lanjut, pembelajaran secara daring menghilangkan rasa cangung yang pada akhirnya membuat mahasiswa menjadi berani berekpresi dalam bertanya dan mengutarakan ide secara bebas.

Pembelajaran daring juga memiliki kelebihan mampu menumbuhkan kemandirian belajar (self regulated learning). Penggunaan aplikasi on line mampu meningkatkan kemandiri belajar (Oknisih, N., \& Suyoto, S., 2019). Kuo et al., (2014) menyatakan bahwa pembelajaran daring lebih bersifat berpusat pada siswa yang menyebabkan mereka mampu memunculkan tanggung jawab dan otonomi dalam belajar (learning autuonomy). Belajar secara daring menuntut mahasiswa mempersiapkan sendiri pembelajarannya, mengevaluasi, mengatur dan secara simultan mempertahankan motiviasi dalam belajar (Sun, 2014; Aina, M.,2016). Sobron, A. N., \& Bayu, R. (2019) menyatakan bahwa pembelajaran daring dapat meningkatkan minat peserta didik.

Pembelajaran daring memiliki tantangan khusus, lokasi mahasiswa dan dosen yang terpisah saat melaksanakan menyebabkan dosen tidak dapat mengawasi secara langsung kegiatan mahasiswa selama proses pembelajaran. Tidak ada jaminan bahwa mahasiswa sunguh-sungguh dalam mendengarkan ulasan dari dosen. Szpunar, Moulton, \& Schacter, (2013) melaporkan dalam penelitiannya bahwa mahasiswa menghayal lebih sering pada perkuliahan daring dibandingkan ketika kuliah tatap muka. Oleh karena itu disarankan pembelajaran daring sebaiknya diselenggarakan dalam waktu tidak lama mengingat mahasiswa sulit mempertahankan konsentrasinya apabila perkuliahan daring dilaksanakan lebih dari satu jam (Khan.,2012).

Hasil penelitian juga melaporkan bahwa tidak sedikit mahasiwa yang kesulitan dalam memahami materi perkuliahan yang diberikan secara daring. Bahan ajar biasa disampaikan dalam bentuk bacaan yang tidak mudah dipahami secara menyeluruh oleh mahasiswa (Sadikin, A., \& Hakim, N., 2019). Mereka berasumsi bahwa materi 
dan tugas tidak cukup karena perlu penjelasan secara langsung oleh dosen. Garrison \& Cleveland-Innes (2005) dan Swan (2002) melaporkan bahwa kelas yang dosennya sering masuk dan memberikan penjelasan memberikan pembelajaran lebih baik dibandingkan kelas yang dosennya jarang masuk kelas dan memberikan penjelasan.

3. Pembelajaran daring memutus mata rantai Penyebaran Covid-19 di Perguruan Tinggi

Wabah Covid-19 adalah jenis wabah yang tingkat penyebarannya sangat tinggi dan cepat. Wabah ini menyerang sistem imun dan pernapasan manusia (Rothan \& Byrareddy, 2020). Pencegahan wabah ini dilakukan dengan menghindari interkasi langsung orang yang terinfeksi dengan orang-orang yang beresiko terpapar virus corona ini (Caley, Philp, \& McCracken, 2008). Mengatur jarak dan kontak fisik yang berpeluang menyebarkan virus disebut social distancing (Bell et al., 2006).

Berbagai upaya untuk menekan mata rantai penyebaran Covid-19 di lingkungan kampus, Universitas Jambi menerapkan aturan pembelajaran daring. Perkuliahan dilakukan menggunakan internet sehingga memudahkan dosen dan mahasiswa berinterkasi secara on line. Dosen dapat membuat bahan ajar yang dapat diakses oleh mahasiswa dimana saja dan kapan saja. Menurut Bell et al., (2017) pembelajaran daring memungkin adanya interaksi melalui web walaupun mereka berada ditempat yang jauh dan berbeda (Arzayeva, et al., 2015). Keberadaan dosen dan mahasiswa yang berada ditempat yang berbeda selama pembelajaran menghilangkan kontak fisik dan mampu mendorong muculnya perilaku social distancing. Menurut Stein (2020) melakukan social distancing sebagai solusi yang baik untuk mencegah penyebaran Covid-19.

Pelaksanaan pembelajaran daring memungkinan mahasiswa dan dosen melaksanakan perkuliahan dari rumah masing-masing. Mahasiswa dapat mengakses materi perkuliahan dan mengirim tugas yang diberikan dosen tanpa harus bertemu secara fisik di kampus. Tindakan ini bisa mengurangi timbulnya kerumunan massa di kampus seperti yang terjadi pada perkuliahan tatap muka. WHO (2020) merekomendasi bahwa menjaga jarak dapat mencegah penularan Covid-19.

Sayangnya, di daerah-daerah yang pelosok dan tidak mempunyai akses internet yang baik pelaksanaan pembelajaran daring menunjukkan kecenderungan yang berbeda. Dalam menyiasati kondisi ini, mahasiswa yang tinggal didaerah yang sinyal internet lemah akan mencari wilayah-wilayah tertentu seperti perbukitan dan wilayah kecamatan untuk dapat terjangkau oleh akses internet.

\section{KESIMPULAN}

Dalam rangka memutus mata rantai penyebaran CSebagai Covid-19 di lingkungan perguruan tinggi, maka Prodi Pendidikan Biologi FKIP Universitas Jambi melaksanakan pembelajaran daring sebagai solusi pelaksanaan pembelajaran. Hasil penelitian menunjukkan mahasiswa memiliki sarana dan prasarana untuk melaksanakan pembelajaran daring. Pembelajaran daring efektif untuk mengatasi pembelajaran yang memungkinan dosen dan mahasiswa berinteraksi dalam kelas virual yang dapat diakses dimana saja dan kapan saja. Pembelajaran daring dapat membuat mahasiswa belajar mandiri dan motivasinya meningkat. Namun, ada 
kelemahan pembelajaran daring mahasiswa tidak terawasi dengan baik selama proses pembelajaran daring. Lemah sinyal internet dan mahalnya biaya kuato menjadi tantangan tersendiri pembelajaran daring. Akan tetapi pembelajaran daring dapat menekan penyebaran Covid-19 di perguruan tinggi.

\section{DAFTAR PUSTAKA}

Aina, M. (2016). Pengembangan Multimedia Interaktif Menggunakan Camtasia Studio 8 Pada Pembelajaran Biologi Materi Kultur Jaringan Untuk Siswa SMA Kelas XI MIA. Biodik, 2(1).

Anggrawan, A. (2019). Analisis Deskriptif Hasil Belajar Pembelajaran Tatap Muka dan Pembelajaran Online Menurut Gaya Belajar Mahasiswa. MATRIK: Jurnal Manajemen, Teknik Informatika Dan Rekayasa Komputer, 18(2), 339-346. https://doi.org/10.30812/matrik.v18i2.411

Anggereini, E. (2017). Pengembangan E-Modul Pembelajaran Lingkungan Hidup Terintegrasi Nilai-Nilai Perilaku Pro Environmental dengan Aplikasi 3D Pageflip Profesional untuk Siswa SMA Sebagai Upaya Menjaga Lingkungan Hidup Berkelanjutan (Sustainable Environment). BIODIK, 3(2), 81-91. https://doi.org/10.22437/bio.v3i2.5499

Arzayeva, M., Rakhimzhanov, K., Abdrahmanova, A., \& Umitkaliev, U. (2015). Special aspects of distance learning in educational system. Anthropologist, 22(3), 449-454. https://doi.org/10.1080/09720073.2015.11891900

Asif, A. R., \& Rahmadi, F. A. (2017). Hubungan tingkat kecanduan gadget dengan gangguan emosi dan perilaku remaja usia 11-12 tahun (Doctoral dissertation, Faculty of Medicine).

Astuti, P., \& Febrian, F. (2019). Blended Learning Syarah: Bagaimana Penerapan dan Persepsi Mahasiswa. Jurnal Gantang, 4(2), 111119. https://doi.org/10.31629/jg.v4i2.1560

Bell, D., Nicoll, A., Fukuda, K., Horby, P., Monto, A., Hayden, F., ... Van Tam, J. (2006). Nonpharmaceutical interventions for pandemic influenza, national and community measures. Emerging Infectious Diseases. https://doi.org/10.3201/eid1201.051371

Bell, S., Douce, C., Caeiro, S., Teixeira, A., Martin-Aranda, R., \& Otto, D. (2017). Sustainability and distance learning: a diverse European experience? Open Learning, 32(2), 95-102. https://doi.org/10.1080/02680513.2017.1319638

Caley, P., Philp, D. J., \& McCracken, K. (2008). Quantifying social distancing arising from pandemic influenza. Journal of the Royal Society Interface. https://doi.org/10.1098/rsif.2007.1197

Chan, N. N., Walker, C., \& Gleaves, A. (2015). An exploration of students' lived experiences of using smartphones in diverse learning contexts using a hermeneutic phenomenological approach. Computers and Education. https://doi.org/10.1016Zj.compedu.2014.11.001

CNNIndonesia. (n.d.-a). 4 Aplikasi Video Conference yang Irit dan Boros Data. Retrieved from https://www.cnnindonesia.com/teknologi/20200330191529-185488422/4-aplikasi- video-conference-yang-irit-dan-boros-data 
CNNIndonesia. (n.d.-b). 65 Kampus Kuliah dari Rumah, Sultan Yogya Ragukan Efektivitas.

Retrieved

from

https://www.cnnindonesia.com/nasional/20200316110707-20-

483756/65kampus-kuliah-dari-rumah-sultan-yogya-ragukan-efektivitas

Darmalaksana, W. (2020). WhatsApp Kuliah Mobile . Fakultas Ushuluddin UIN Sunan Gunung Djati Bandung.

Enriquez, M. A. S. (2014). Students ' Perceptions on the Effectiveness of the Use of Edmodo as a Supplementary Tool for Learning. DLSU Research Congress. https://doi.org/10.1017/CBO9781107415324.004.

Firman, F., \& Rahayu, S. (2020). Pembelajaran Online di Tengah Pandemi Covid19. Indonesian Journal of Educational Science (IJES), 2(2), 81-89.

Garrison, D. R., \& Cleveland-Innes, M. (2005). in Online Learning : Interaction Is Not Enough.

American Journal of Distance Education. https://doi.org/10.1207/s15389286ajde1903

Gikas, J., \& Grant, M. M. (2013). Mobile computing devices in higher education: Student perspectives on learning with cellphones, smartphones \& social media. Internet and Higher Education. https://doi.org/10.1016/jiheduc.2013.06.002

Gokfearslan, §., Mumcu, F. K., Haß̧laman, T., \& £evik, Y. D. (2016). Modelling smartphone addiction: The role of smartphone usage, self-regulation, general self-efficacy and cyberloafing in university students. Computers in Human Behavior. https://doi.org/10.1016/j.chb.2016.05.091

He, W., Xu, G., \& Kruck, S. (2014). Online IS Education for the 21st Century . Journal of Information Systems Education.

Jamaluddin, D., Ratnasih, T., Gunawan, H., \& Paujiah, E. (2020). Pembelajaran daring masa pandemik Covid-19 pada calon guru: hambatan, solusi dan proyeksi. $L P 2 M$.

Iftakhar, S. (2016). GOOGLE CLASSROOM: WHAT WORKS AND HOW? Journal of Education and Social Sciences.

Kay, R. H., \& Lauricella, S. (2011). Exploring the Benefits and Challenges of Using Laptop Computers in Higher Education Classrooms: A Formative Analysis. Canadian Journal of Learning and Technology /La Revue Canadienne de I 'apprentissage et de La Technologie. https://doi.org/10.21432/t2s598

Kim, Y., Wang, Y., \& Oh, J. (2016). Digital Media Use and Social Engagement: How Social Media and Smartphone Use Influence Social Activities of College Students. Cyberpsychology, Behavior, and Social Networking. https://doi.org/10.1089/cyber.2015.0408

Korucu, A. T., \& Alkan, A. (2011). Differences between m-learning (mobile learning) and elearning, basic terminology and usage of m-learning in education. Procedia - Social and Behavioral Sciences. https://doi.org/10.1016/j. sbspro.2011.04.029

Kumar, V., \& Nanda, P. (2018). Social Media in Higher Education. International Journal of Information and Communication Technology Education. https://doi.org/10.4018/ijicte.2019010107

Kuntarto, E. (2017). Keefektifan Model Pembelajaran Daring dalam Perkuliahan Bahasa Indonesia di Perguruan Tinggi. Indonesian Language Education and 
Literature, 3(1), 99-110. 10.24235/ileal.v3i1.1820

Kuo, Y. C., Walker, A. E., Schroder, K. E. E., \& Belland, B. R. (2014). Interaction, Internet self-efficacy, and self-regulated learning as predictors of student satisfaction in online education courses. Internet and Higher Education. https://doi.org/10.1016/jiheduc.2013.10.001

Kwon, M., Lee, J. Y., Won, W. Y., Park, J. W., Min, J. A., Hahn, C., ... Kim, D. J. (2013). Development and Validation of a Smartphone Addiction Scale (SAS). PLoS ONE. https://doi.org/10.1371/journal.pone.0056936

Lau, W. W. F. (2017). Effects of social media usage and social media multitasking on the academic performance of university students. Computers in Human Behavior. https://doi.org/10.1016/j.chb.2016.11.043

Miles, M. B., \& Huberman, M. (1994). Qualitative Data Analysis Second Edition. SAGE Publications.

Milman, N. B. (2015). Distance Education. In International Encyclopedia of the Social \& Behavioral Sciences: Second Edition. https://doi.org/10.1016/B978-0-08097086-8.92001-4

Molinda, M. (2005), Instructional Technology and Media for Learning New Jersey Colombus, Ohio

Moore, J. L., Dickson-Deane, C., \& Galyen, K. (2011). E-Learning, online learning, and distance learning environments: Are they the same? Internet and Higher Education. https://doi.org/10.1016/jiheduc.2010.10.001.

Naserly, M. K. (2020). IMPLEMENTASI ZOOM, GOOGLE CLASSROOM, DAN WHATSAPP GROUP DALAM MENDUKUNG PEMBELAJARAN DARING (ONLINE) PADA MATA KULIAH BAHASA INGGRIS LANJUT (Studi Kasus Pada 2 Kelas Semester 2, Jurusan Administrasi Bisnis, Fakultas Ekonomi dan Bisnis, Universitas Bina Sa. Aksara Public, 4(2), 155-165.

Oknisih, N., \& Suyoto, S. (2019). PENGGUNAAN APLEN (APLIKASI ONLINE) SEBAGAI UPAYA KEMANDIRIAN BELAJAR SISWA. In SEMINAR NASIONAL PENDIDIKAN DASAR (Vol. 1, No. 01)

Pangondian, R. A., Santosa, P. I., \& Nugroho, E. (2019). Faktor-Faktor Yang Mempengaruhi Kesuksesan Pembelajaran Daring Dalam Revolusi Industri 4.0. In Seminar Nasional Teknologi Komputer \& Sains (SAINTEKS) (Vol. 1, No. 1).

Rahadian, D. (2017). Teknologi informasi dan komunikasi (tik) dan kompetensi teknologi pembelajaran untuk pengajaran yang berkualitas. TEKNOLOGI PEMBELAJARAN, 2(1).

Rothan, H. A., \& Byrareddy, S. N. (2020). The epidemiology and pathogenesis of coronavirus disease (COVID-19) outbreak. Journal of

Autoimmunity. https ://doi.org/ 10.1016/j.jaut.2020.102433

Sadikin, A., \& Hakim, N. (2019). Pengembangan Media E-Learning Interaktif Dalam Menyongsong Revolusi Industri 4.0 Pada Materi Ekosistem Untuk Siswa SMA. BIODIK, 5(2), 131-138. https://doi.org/10.22437/bio.v5i2.7590

Salman Khan. (2012). The One World Schoolhouse. In Hachette Book Group. https://doi.org/10.1111/edth. 12072

Sicat, A. S. (2015). Enhancing College Students' Proficiency in Business Writing Via Schoology. International Journal of Education and Research. 
Sadikin, A., Johari, A., \& Suryani, L. (2020). Pengembangan multimedia interaktif biologi berbasis website dalam menghadapi revolusi industri 4.0. Edubiotik: Jurnal Pendidikan, Biologi Dan Terapan, 5(01), 18-28. https://doi.org/10.33503/ebio.v5i01.644

Siddiqui, S., \& Singh, T. (2016). Social Media its Impact with Positive and Negative Aspects. International Journal of Computer Applications Technology and Research. https://doi.org/10.7753/ijcatr0502.1006

So, S. (2016). Mobile instant messaging support for teaching and learning in higher education. Internet and Higher Education. https://doi.org/10.1016Zj.iheduc.2016.06.001

Stein, R. (2020). COVID-19 and Rationally Layered Social Distancing . International Journal of Clinical Practice. https://doi.org/10.1111/ijcp. 13501

Sobron, A. N., \& Bayu, R. (2019). PERSEPSI SISWA DALAM STUDI PENGARUH DARING LEARNING TERHADAP MINAT BELAJAR IPA. SCAFFOLDING: Jurnal Pendidikan Islam dan Multikulturalisme, 1(2), 30-38.

Sun, P. C., Tsai, R. J., Finger, G., Chen, Y. Y., \& Yeh, D. (2008). What drives a successful eLearning? An empirical investigation of the critical factors influencing learner satisfaction. Computers and Education. https://doi.org/10.1016Zj.compedu.2006.11.007

Sun, S. Y. H. (2014). Learner perspectives on fully online language learning. Distance Education. https://doi.org/10.1080/01587919.2014.891428

Swan, K. (2002). Building Learning Communities in Online Courses: the importance of interaction. Education, Communication \& Information. https://doi.org/10.1080/1463631022000005016

Szpunar, K. K., Moulton, S. T., \& Schacter, D. L. (2013). Mind wandering and education: From the classroom to online learning. Frontiers in Psychology. https://doi.org/10.3389/fpsyg.2013.00495

WHO. (n.d.). Points of entry and mass gatherings. Retrieved March 28, 2020, from https://www.who.int/emergencies/diseases/novel-coronavirus-2019/technicalguidance/points-of-entry-and-mass-gatherings

Yandwiputra, A. R. (n.d.). Kuliah Jarak Jauh karena Virus Corona, UI: Bukan Lockdown. Retrieved from https://metro.tempo.co/read/1319537/kuliah-jarakjauh-karena-virus- corona-ui-bukan-lockdown

Zhang, D., Zhao, J. L., Zhou, L., \& Nunamaker, J. F. (2004). Can e-learning replace classroom learning? Communications of the ACM. https://doi.org/10.1145/986213.986216 